\title{
A Proposal for Measuring Interactivity that Brings Learning Effectiveness
}

\author{
Tosh Yamamoto* \\ Department of Media Informatics, \\ Kanazawa Institute of Technology, Japan \\ E-mail: caitosh@neptune.kanazawa-it.ac.jp \\ *Corresponding author
}

\begin{abstract}
It is proposed in this paper that some type of way to measure and visualize interactivity in the multimedia or e-Learning contents is necessary in order to clearly identify interactivity that brings learning effectiveness. Interactivity during learning will arouse students' intellectual curiosity and motivate them to learn further. Although the interaction in the communication between the teacher and his/her students in a regular classroom is ideal, it is not possible to maintain the equivalence in the multimedia or e-Learning contents. In order to rigorously formalize the field of measuring interactivity as a theory, theoretical constructs such as interactivity, interest, knowledge, and experience are redefined first. Then, the defined "interactivity" is broken down to subcomponents to develop an assessment tool for the interactivity which brings learning effectiveness. In the end, it is proved that the interactivity in learning can be measured.
\end{abstract}

Keywords: e-Learning, Interactivity, Learning, Interests in Learning.

Biographical notes: Tosh Yamamoto, Ph.D. is a professor in the department of Media Informatics at Kanazawa Institute of Technology. He has been active in the area of e-Learning specialized in interactivity in e-Learning that brings learning effectiveness. He has been researching on how to design a robust ePortfolio system in the higher education.

\section{Introduction}

The goal of this paper is to propose how to measure interactivity in e-Learning that brings higher learning outcome. The term "interactivity" has been used in a variety of ways in the field of media technology. Journal articles and conference presentations have been using this term as a buzz word to attract readers and audience. The meaning of the term "interactivity" has been so vague and flexible that anyone could interpret it in the way they wanted for the sake of supporting their arguments or refuting others' arguments. Even the educational software business called software on a CD-ROM itself interactive multimedia. It is about time to have a clear definition of what interactivity is so that scholars specialized in multimedia can speak the same language to aim at better quality of the instruction in out time.

In this paper, we will try to define and measure interactivity and to propose how to visualize its effectiveness. Because in any research, theoretical constructs, 
methodology, and framework are the most important starting point of the research, we will define interactivity that brings learning effectiveness first.

\section{Defining Interactivity}

In order to narrow down the definition of "interactivity," let us limit ourselves to the school environment where some type of instruction and learning are in progress. Also for the sake of the theory building, let us view interactivity from the perspective of the learner instead of the producer of instructional materials or designers or even teachers. Furthermore, in order to limit our field of research, let us define the environment for learning only through the standard networked multimedia computer which has a capability to generate digitized sounds, display digitized videos, capture images through a camera, and record the learner's voice as well as the conventional input devices such as a mouse and a keyboard, which can be commonly observed in a computer lab or classroom in schools.

\subsection{Backgrounds and Ground Work}

Between 1890 and 1920, the idea of creating teaching machines so that students can receive the uniform instructions to develop the same quality of development as an output of education was developed as the wave of the industrialization as well as the behaviorism came into the field of education. But soon afterwards, the curriculum developers realized the mistakes and shift the attention to the individual progress of students. During the last 10 to 14 years, the use of computers and other technical devices was promoted as a way to augment learning. Prospect is that more and more computers will be used in schools to augment learning. Our position here is that the instructional materials are for augmenting learning in schools where teachers play a major role in children's learning.

We should also keep in mind that the use of computers in schools in the last decade is still very new and immature. Even in higher education, Geoghegan (1994) estimates that of all the educational technologies implemented, no more than five percent of instructors use computers as anything more than high-tech substitutes for the blackboard and the overhead projector. He claims that identifying and extending creative use of educational courseware should be central to studies dealing with implementation. Geoghegan's point is right in the sense that teachers are still trying to identify the status and function of computers in classrooms. When it comes to teachers having their students use computers to learn knowledge, we still have to go a long way. For these reasons, it would be helpful to have an important aspect, interactivity, in the use of computer in classrooms.

To refine our working definition of "interactivity," we would like to start from the origin of learning. Dewey (1913) may be a good starting point for us in which he categorizes four types of interest that humans have. Dewey defines interest as an activity engaging a person in a whole-hearted way. Interest does not just sit in the human mind. Instead it operates itself outward to link the internal power to the outside of the self. When this process is accomplished, the human gain some satisfaction. Thus, interest is a trigger of a subject-matter and it will bring a certain result. Dewey consider this concept of activity as an important education principle. Since educative interests vary indefinitely with age, with individual native endowments, with prior experience, and with social opportunities, it is not possible to list exhaustively. Dewey categorizes four types of interests. They are: (1) instinctive interest, (2) sensorimotor interest, (3) distinctive 
intellectual interest, (4) social interest, which are summarized below respectively. Following the description of each type of interest, the use and application of computers are considered from each perspective of interest.

\subsection{Instinctive Interest}

Instinctive interest is more or less learning to survive, which humans share with other animals. In addition, humans have interests to learn other things than just related to survival. Dewey calls this inherent instructive ability of interest "a love of learning." This interest involves physical, mental, and intellectual elements. Developmentally, children are "interested" in the organic senses such as sight, touch, sound, taste, etc. and link their functions with the brain. Children acquire this type of interest before the preschool period. At this stage, children also learn how to coordinate more than one organic sense. This instinctive interest does not directly concern us because it is acquired before schooling starts.

\subsection{Sensorimotor Interest}

Sensorimotor interest involves physical activity, where children are interested in commands of the sensorimotor apparatus of the body. Children show interest in their command of eye-hand coordination at a higher level, and eventually in control over external objects by means of tools, in other words, control of applying one material to another. Interest in symbol manipulation is another example.

Besides sports that use a ball such as soccer, tennis, etc., computers can be applicable in amplifying this type of interest. Various input systems such as a mouse, a keyboard, a joystick, a touch pad, and a tablet and a pen, encourage and reinforce the development of sensorimotor learning because they require not only eye-hand coordination but also the command of external tools. The processor and output devices, such as the computer screen, give immediate feedback of the activity.

Computers can also provide children with opportunities to enhance symbolic interest which is part of sensorimotor interest. Incorrect spelling, for example, can receive immediate feedback as misspelled words are highlighted. Even in more advanced symbolic interest can be enhanced by visualization software such as Mathematica or Maple, which displays mathematical formula in 3-D images. These interests of children may be satisfied by human teachers, but in a classroom situation where there are often more than 20 students, computers are more efficient in performing symbol manipulation exercises and individualized immediate feedback to errors and visualization.

It follows that sensorimotor interest is a significant area where computers can play an active role in education. That is, with computers, the one-on-one tutoring environment can be achieved easily in a classroom.

\subsection{Distinctive Intellectual Interest}

The distinctive intellectual interest is concerned with the interest in discovering or finding out what happens under given circumstances. This interest is realized in activities such as planning ahead, taking notice of what happens, relating the process and its result. Because the fundamental principle of science is connected with the relation of cause and effect, this type of interest must be enhanced and amplified in schools once children show this type of interest. This interest requires higher order thinking, primarily because it involves more abstract concepts.

Like the area of sensorimotor interest, computers would be highly more effective than real teachers in this area. The technology of virtual reality can create situations so 
that students can take individual flight or driving lessons, or even learning how to operate a nuclear power plant or how to conduct a surgical operation. Life-threatening experiences such as learning to drive on a hazardous road or to fly an aircraft in a bad weather condition cannot be conducted in a real classroom. Furthermore, dangerous chemistry or physics experiments can also be performed in the virtual reality lab. Students can also learn how the Universe develops and how cancer or AIDS affects human bodies from various angles with computer visualization.

In order to satisfy children's distinctive intellectual interest, and provide stimulus in the form of visualization of complex structures or variables, computers can perform a better job than human teachers alone. There is no comparison.

\subsection{Social Interest}

Social interest is defined as interest in persons. This is a strong special interest, in which a child's intense concern with other persons is involved. Children are constantly dependent upon others for support and guidance. Social interest is closely related to our instinctive human nature to pay attention to people and wishes to be intimately bonded to them. Distinctive social instincts such as sympathy, imitation, love, and desire for approval are realized activities of social interest. This social interest of children is deeply intertwined with that of other children, or the interests of their teachers and family members, as well as their collective hopes, desires, plans, and experiences.

Due to its nature of social interest, social interest as well as hopes, desires, plans, and experiences cannot be shared with other artificial intelligence forms. Other artificial intelligence forms cannot be like human to share the cultural heritage and knowledge in the democratic society. Social interest must be fulfilled only by human teachers because human teachers can share this social interest with children. There is no room for computers to replace human teachers in this respect. There is no question about it.

However, it should be noted that the Internet, listserv, forum discussion boards, on-line chat rooms and email can be good tools to reinforce and satisfy social interest of children. They bring efficiency in communication between children and teachers. Here the computer serves as media for communication between children and teachers.

\section{Definition of Knowledge and Learning}

Having defined the four types of interest, another question that we cannot avoid before moving forward is the definition of knowledge and learning. T. Reeves and S. Harmon (1994) argue for a pedagogical dimension of epistemology as measure for Interactive Multimedia. They define epistemology as theories about the nature of knowledge and maintain that this dimension is a key to link the knowledge to be learned by students and the knowledge or reality held by the interactive multimedia designer. (T. Reeves and $\mathrm{S}$. Harmon, 1994, pp. 472-505).

We should look at T. Reeves and S. Harmon (1994) and Tobin and Dawson (1992) as our starting point. They use the following thirteen pedagogical dimensions to measure the interactive multimedia. The dimensions are shown in Table 1. 
Table 1. Pedagogical Dimensions for the Interactive Multimedia

\begin{tabular}{|l|l|}
\hline Epistemology & Cooperative Learning \\
\hline Underlying Psychology & Pedagogical Philosophy \\
\hline Instructional Sequencing & Goal Orientation \\
\hline Role of Instructor & Experiential Value \\
\hline Motivation & Structure \\
\hline $\begin{array}{l}\text { Accommodation of Individual } \\
\text { Differences }\end{array}$ & User Activity \\
\hline Learner Control & \\
\hline
\end{tabular}

Further, they also use the following ten components for the user-interface ratings. The ten components are shown in Table 2.

Table 2. User Interface Ratings for the Interactive Multimedia

\begin{tabular}{|l|l|}
\hline Ease of use & Navigation \\
\hline Cognitive Load & Mapping \\
\hline Screen Design & Knowledge Space Compatibility \\
\hline Information Presentation & Media Integration \\
\hline Aesthetics & Overall Functionality \\
\hline
\end{tabular}

It is obvious that their intention is to evaluate the interactive multimedia. But we notice immediately that there is no categories for evaluating the intensity or learning effectiveness of interactivity between the contents and the learner or the time lag between the learner's reaction and its feedback from the interactive multimedia. This evaluation can easily be applied to evaluate physical textbooks in the classroom. As pointed out earlier in the paper, T. Reeves and S. Harmon (1994) and Tobin and Dawson (1992) use the word "interactive" in a very vague sense. Not all instructional materials that are delivered via computer screen are interactive multimedia. Considering the fact that their articles are written during the time when computer software for education was beginning to emerge, they did not have any choice to avoid such vagueness in the use of the term "interactive."

\subsection{Dewey's Definition of Knowledge}

For these reasons, we need to seek for more practical definition of what knowledge is and what experience is in the school environment. It seems that what works best for the sake of our discussion is the definition given by Dewey (1916) and Dewey (1938). What follows is Dewey's educational summary.

For Dewey, the focus is to determine the place of thinking in experience. The nature of experience are of two folds: (1) doing or trying and (2) something which is undergone in consequence. Dewey believed that the two sides are not separable. "Thinking" is the accurate and deliberate instituting of connections between what is done and its consequences. "Thinking" makes the details of links explicit in the form of 
relationships. "Stimulus of thinking" is our desire to determine the significance of some act, performed or to be performed. Dewey believed the following steps in "Thinking."

(1) Existing conditions have to be carefully scrutinized

(2) The implications of the hypothesis have to be developed. i.e., reasoning

(3) The suggested solution - the idea or theory - has to be tested by acting upon it.

(4) If it brings about certain consequences (or certain determinate changes,) in the world, it is considered as valid. If it does not, the suggested solution is modified, or another trial is made.

The step (1) is the sense of a problem. The step (2) is the observation of conditions. The step (3) is the formation and rational elaboration of a suggested conclusion. The step (4) is the active experimental testing. As noted from the description, these steps are the basic principle of the empirical science. We can view Dewey's departure from Behaviorism and Empiricism where people are born with tabula rasa and this empty vessel is eventually filled with experiences.

It is important to emphasize that all thinking results in knowledge, but the value of knowledge, depend on the application of knowledge in thinking. It is outside of the knowledge to evaluate the value of it.

Having defined the types of interest that the learner has, let us try to define interactivity. Interactivity is a bridge between the knowledge which is external to the learner and which is to be acquired by him or her, on the one hand, and the interest in the mind of the learner, on the other. Furthermore, when we think of interactivity, there is another important factor to be considered. That is a psychological factor, which is best described in Pearce (1997). "Interactivity craves meaning. It needs motivation, and it longs for emotional, as well as intellectual content. It is difficult at best to convince a person that it would be a good idea to penetrate the fourth wall, to break the artificial boundary between man and media set up by the conventions of theater, film, and television. People are alternately intimidated or unmotivated by experiences that require taking risks. They don't like to make mistakes. They don't want to have unnecessary attention called to them." (Pearce, 1997, p.219).

It follows that interactivity not only creates the intensity of learning, but also creates the environment where students take risks. If students start thinking "what is wrong with what we already have as a bridge to connect our interest in mind and the external knowledge?", which is where the educational enterprise of implementing interactivity to augment learning ends. Thus, good interactive interface must remove students' natural inhibitions and draw them into the process by giving them a good enough reason to take a risk.

\subsection{Working Definition of "Interactivity"}

Now we are ready to make our working definition of "interactivity" incorporating the arguments above. Interactivity happens during the process of learning. Learning is outward activity of interest in the learner to its corresponding knowledge which exits external to the learner's experience. Only knowledge judged by the learner's prior experience in the school environment which is a reflection of the democratic society can become his or her experience. Interactivity is one of the means to link interest of the learner and its counterpart external knowledge to be acquired during the learning process. Also interactivity is multi-channeled. If interest of learner is satisfied, the interactivity is successful. If it is not satisfied, interactivity is a failure. Te outcome of interactivity is a 
gain of experience or re-evaluation of prior experience, which triggers more interests and lead to the learner into a new stage of experience.

T. Reeves (1999) claimed that "interactivity" must contain three aspects: (1) content process, (2) tasks to compete, (3) problems to solve. He points out that although most educational web sites cover (1) content process, they miss (2) tasks to complete and (3) problems to solve. That is, what is missing is the most important component of what teachers want their students to do.

Two more components must be added to Reeves' observation. They are (4) feedback for (2) and (3), and (5) frequencies of feedback. As for (4) feedback for (2) and (3), if the educational web site just throws tasks and problems to students and does not follow up on them, there is no point to implement and evaluate (2) and (3). In explaining (5) frequencies of feedback, considerations such as how much time is given before feedback and how often the assigned task and problem are checked are important.

Having covered all components of interactivity, we further assume that interactivity is measurable in quantification. We see our first attempt to measure level of intensity of interactivity so that this project be a quantitative experiment.

\section{Quantification of Interactivity}

Our major concern in this section is how to convert the degree of interactivity (nondiscrete) into discrete scale so that the interactivity can be measured and used in a quantitative research. Following the predecessors in the behavioral psychology, our first step is to set up a probing tool to dissect interactivity into various subcomponents and then, the second step is to devise a type of Likert scale to measure those subcomponents.

\subsection{Subcomponents of Interactivity}

We will attempt to list all subcomponents of a probing tool for interactivity. We should keep in mind that interactivity is not about technology and that it is about students and their experience in learning. The most important aspect of an interactive process is what goes on inside the head of the learner. Therefore, in a sense, we are trying to measure what goes on in the head of the learner. For ease of exposition, subcomponents of a probing tool are shown in a form of list.

Components of interactivity from the learner's perspective are as follows:

- [ motivation trigger or interest trigger ] Would you want to stay on the page and learn?

- [ justification ] Why would you like to learn from this page?

- [ constant motivation trigger ] Why would you like to keep learning from this page or site?

- [ continuing motivation ] Why would you want to do it again in order to learn?

- [ psychological reward ] What would you get by learning this? What is the payoff?

- [ variety of payoffs ] Are you satisfied with varieties of payoffs based on different actions?

- [ learning by doing ] Are you learning, gaining experience as you work on the material?

- [ concept visualization ] Does it help you visualize concepts? 
- [ satisfaction of interest ] Are you satisfied by having learned what you wanted to learn at the initial stage of the lesson?

- [ frequency of attention ] Were you given frequent attention by the teacher as you learned?

Furthermore, components of interactivity from the teacher's perspective are as follows:

- [ learning trigger ] Are there things on the page or site to spark insight and discovery?

- [ new connection ] Are there features to create new connections in the student's mind?

- [ routine breaker ] Are there surprises implemented to break routine activities?

- [ emotion ] Are there features to make students laugh, smile, mad, even cry?

- [ feedback ] Are there features to give feedback to what students question or ask?

- [ frequency of feedback ] How frequently is feedback given to students?

- [ time lag before feedback ] How long do students wait before receiving feedback? Is the time lag effectively used?

- [ variety of payoffs ] Is there enough variety to have different payoffs based on different actions?

As noted before, this is an on-going project to make an exhaustive listing of subcomponents of interactivity.

\subsection{Rubrics}

What follows is a prototype version of the rubric to measure and visualize interactivity from the learner's perspective. See Table 3. Each component is broken down to six scales. The total score is fifty points. The higher the point is, the more interactive the learning contents is. The score of each component could be displayed in the radar chart to visually show strong points as well as weak points. 
Table 3. Rubrics: Interactivity from the learner

\begin{tabular}{|c|c|c|c|c|c|c|c|c|}
\hline \multicolumn{4}{|c|}{ Components of interactivity from the learner's perspective } & \multirow[b]{2}{*}{3} & & \multirow[b]{2}{*}{0} & \multirow[b]{2}{*}{ subtotal } \\
\hline Component & Description & 5 & 4 & & 2 & 1 & & \\
\hline $\begin{array}{l}\text { [ motivation } \\
\text { trigger or interest } \\
\text { trigger ] }\end{array}$ & \begin{tabular}{|l|} 
Would you want \\
to stay on the \\
page and learn?
\end{tabular} & $\begin{array}{l}\text { All learners are } \\
\text { interested in the } \\
\text { contents and tend } \\
\text { to stay on the } \\
\text { page to learn. } \\
\end{array}$ & $\begin{array}{l}\text { Most learners are } \\
\text { interested in the } \\
\text { contents and tend } \\
\text { to stay on the } \\
\text { page to learn. }\end{array}$ & $\begin{array}{l}\text { Some learners } \\
\text { show interests in } \\
\text { the contents and } \\
\text { tend to stay on } \\
\text { the page to learn. } \\
\end{array}$ & $\begin{array}{l}\text { A few learners } \\
\text { show interests in } \\
\text { the contents and } \\
\text { tend to stay on } \\
\text { the page to learn. }\end{array}$ & $\begin{array}{l}\text { Few learners } \\
\text { Ishow interests in } \\
\text { the contents and } \\
\text { tend to stay on } \\
\text { the page to learn. }\end{array}$ & $\begin{array}{l}\text { A learner does } \\
\text { not want to stay } \\
\text { on the page or } \\
\text { skip to the next } \\
\text { page. }\end{array}$ & \\
\hline [ justification ] & \begin{tabular}{|l|} 
Why would you \\
like to learn from \\
this page?
\end{tabular} & $\begin{array}{l}\text { All syllabus } \\
\text { contents is } \\
\text { clearly reflected } \\
\text { on the page. }\end{array}$ & $\begin{array}{l}\text { Most syllabus } \\
\text { contents is } \\
\text { reflected on the } \\
\text { page. }\end{array}$ & $\begin{array}{l}\text { Some syllabus } \\
\text { contents is } \\
\text { reflected on the } \\
\text { page. }\end{array}$ & $\begin{array}{l}\text { A few syllabus } \\
\text { contents is } \\
\text { reflected on the } \\
\text { page. }\end{array}$ & $\begin{array}{l}\text { Few syllabus } \\
\text { icontents is } \\
\text { Ireflected on the } \\
\text { page. }\end{array}$ & $\begin{array}{l}\text { The syllabus } \\
\text { contents is not } \\
\text { reflected on the } \\
\text { page. }\end{array}$ & \\
\hline $\begin{array}{l}\text { [ constant } \\
\text { motivation } \\
\text { trigger ] }\end{array}$ & $\begin{array}{l}\text { Why would you } \\
\text { like to keep } \\
\text { learning from } \\
\text { this page or site? }\end{array}$ & \begin{tabular}{|l} 
Motivation \\
triggers are \\
omnipresent.
\end{tabular} & $\begin{array}{l}\text { Motivation } \\
\text { triggers are on } \\
\text { most pages. }\end{array}$ & $\begin{array}{l}\text { Motivation } \\
\text { triggers are } \\
\text { frequently used } \\
\text { on pages. } \\
\end{array}$ & $\begin{array}{l}\text { Motivation } \\
\text { triggers are on } \\
\text { some pages. }\end{array}$ & $\begin{array}{l}\text { Motivation } \\
\text { triggers are on a } \\
\text { ifew pages. }\end{array}$ & $\begin{array}{l}\text { Motivation } \\
\text { triggers are not } \\
\text { present. }\end{array}$ & \\
\hline $\begin{array}{l}\text { [ continuing } \\
\text { motivation ] }\end{array}$ & $\begin{array}{l}\text { Why would you } \\
\text { want to do it } \\
\text { again in order to } \\
\text { learn? }\end{array}$ & $\begin{array}{l}\text { Learning triggers } \\
\text { are omnipresent. }\end{array}$ & $\begin{array}{l}\text { Learning triggers } \\
\text { are present in } \\
\text { most pages. }\end{array}$ & $\begin{array}{l}\text { Learning triggers } \\
\text { are present in } \\
\text { some pages. }\end{array}$ & $\begin{array}{l}\text { Learning triggers } \\
\text { are present in a } \\
\text { few pages. }\end{array}$ & $\begin{array}{l}\text { Learning triggers } \\
\text { are rarely used. }\end{array}$ & $\begin{array}{l}\text { No sign of } \\
\text { motivation } \\
\text { reminder. }\end{array}$ & \\
\hline $\begin{array}{l}\text { [ psychological } \\
\text { reward ] }\end{array}$ & $\begin{array}{l}\text { What would you } \\
\text { get by learning } \\
\text { this? What is the } \\
\text { payoff? }\end{array}$ & $\begin{array}{l}\text { Constant verbal } \\
\text { rewards are given } \\
\text { when a learner } \\
\text { accomplishes a } \\
\text { learning } \\
\text { objective. } \\
\end{array}$ & $\begin{array}{l}\text { In most sections, } \\
\text { verbal rewards } \\
\text { are given. }\end{array}$ & $\begin{array}{l}\text { In some sections, } \\
\text { verbal rewards } \\
\text { are given. }\end{array}$ & $\begin{array}{l}\text { A few rewards } \\
\text { are given } \\
\text { throughout the } \\
\text { course. }\end{array}$ & $\begin{array}{l}\text { IVerbal rewards } \\
\text { are rarely given. }\end{array}$ & $\begin{array}{l}\text { No rewards are } \\
\text { given. }\end{array}$ & \\
\hline $\begin{array}{l}\text { [ variety of } \\
\text { payoffs ] }\end{array}$ & $\begin{array}{l}\text { Are you satisfied } \\
\text { with varieties of } \\
\text { payoffs based on } \\
\text { different actions? }\end{array}$ & $\begin{array}{l}\text { Varieties of } \\
\text { learning actions } \\
\text { are implemented. }\end{array}$ & $\begin{array}{l}\text { Some varieties of } \\
\text { learning actions } \\
\text { are implemented. }\end{array}$ & $\begin{array}{l}\text { A few varieties of } \\
\text { learning actions } \\
\text { are implemented. }\end{array}$ & $\begin{array}{l}\text { Few varieties of } \\
\text { learning actions } \\
\text { are implemented. }\end{array}$ & $\begin{array}{l}\text { A variety of } \\
\text { learning actions } \\
\text { lare rarely used. }\end{array}$ & $\begin{array}{l}\text { No variety of } \\
\text { learning action is } \\
\text { employed. }\end{array}$ & \\
\hline $\begin{array}{l}\text { [ learning by } \\
\text { doing ] }\end{array}$ & \begin{tabular}{|l|} 
Are you \\
learning, gaining \\
experience as \\
you work on the \\
material? \\
\end{tabular} & $\begin{array}{l}\text { Hands-on and } \\
\text { Head-on learning } \\
\text { materials are } \\
\text { omnipresent. } \\
\end{array}$ & $\begin{array}{l}\text { Hands-on and } \\
\text { Head-on learning } \\
\text { materials are } \\
\text { present on most } \\
\text { pages. } \\
\end{array}$ & $\begin{array}{l}\text { A few hands-on } \\
\text { and head-on } \\
\text { learning } \\
\text { materials are } \\
\text { omnipresent. }\end{array}$ & $\begin{array}{l}\text { Few hands-on } \\
\text { and head-on } \\
\text { learning } \\
\text { materials are } \\
\text { present. }\end{array}$ & $\begin{array}{l}\text { Hands-on and } \\
\text { Ihead-on learning } \\
\text { Imaterials are } \\
\text { rarely present. }\end{array}$ & $\begin{array}{l}\text { No hands-on and } \\
\text { head-on learning } \\
\text { materials are } \\
\text { present. }\end{array}$ & \\
\hline $\begin{array}{l}\text { [ concept } \\
\text { visualization ] }\end{array}$ & $\begin{array}{l}\text { Does it help you } \\
\text { visualize } \\
\text { concepts? }\end{array}$ & $\begin{array}{l}\text { Concept } \\
\text { visualization is } \\
\text { used in all pages. }\end{array}$ & $\begin{array}{l}\text { Concept } \\
\text { visualization is } \\
\text { used in most } \\
\text { pages. }\end{array}$ & \begin{tabular}{|l|} 
Concept \\
visualization is \\
used in some \\
pages.
\end{tabular} & $\begin{array}{l}\text { Concept } \\
\text { visualization is } \\
\text { used in a few } \\
\text { pages. }\end{array}$ & $\begin{array}{l}\text { Concept } \\
\text { Ivisualization is } \\
\text { Irarely used. }\end{array}$ & $\begin{array}{l}\text { No concept } \\
\text { visualization is } \\
\text { used. }\end{array}$ & \\
\hline $\begin{array}{l}\text { [ satisfaction of } \\
\text { interest ] }\end{array}$ & $\begin{array}{l}\text { Are you satisfied } \\
\text { by having learned } \\
\text { what you wanted } \\
\text { to learn at the } \\
\text { initial stage of } \\
\text { the lesson? } \\
\end{array}$ & $\begin{array}{l}\text { Learning goal is } \\
\text { constant } \\
\text { throughout the } \\
\text { contents. }\end{array}$ & $\begin{array}{l}\text { Learning goal is } \\
\text { reflected on the } \\
\text { contents in most } \\
\text { pages. }\end{array}$ & $\begin{array}{l}\text { Learning goal is } \\
\text { reflected on the } \\
\text { contents in some } \\
\text { pages. }\end{array}$ & $\begin{array}{l}\text { Learning goal is } \\
\text { reflected on the } \\
\text { contents in a few } \\
\text { pages. }\end{array}$ & $\begin{array}{l}\text { Learning goal is } \\
\text { somewhat } \\
\text { Ireflected on the } \\
\text { contents. }\end{array}$ & $\begin{array}{l}\text { Learning goal is } \\
\text { not clearly } \\
\text { reflected on the } \\
\text { contents. }\end{array}$ & \\
\hline $\begin{array}{l}\text { [ frequency of } \\
\text { attention ] }\end{array}$ & $\begin{array}{l}\text { Were you given } \\
\text { frequent attention } \\
\text { by the teacher as } \\
\text { you learned? }\end{array}$ & $\begin{array}{l}\text { A learner is } \\
\text { constantly given } \\
\text { attention by the } \\
\text { facilitator. }\end{array}$ & $\begin{array}{l}\text { A learner is } \\
\text { frequently given } \\
\text { attention by the } \\
\text { facilitator. }\end{array}$ & $\begin{array}{l}\text { A learner is } \\
\text { sometimes given } \\
\text { attention by the } \\
\text { facilitator. }\end{array}$ & $\begin{array}{l}\text { A learner is } \\
\text { somewhat given } \\
\text { attention by the } \\
\text { facilitator. }\end{array}$ & $\begin{array}{l}\text { A learner is } \\
\text { Irarely given } \\
\text { Iattention by the } \\
\text { 'facilitator. }\end{array}$ & $\begin{array}{l}\text { A learner is } \\
\text { constantly given } \\
\text { attention by the } \\
\text { facilitator. }\end{array}$ & \\
\hline Total SCORE : & & & & & & 1 & & \\
\hline
\end{tabular}

In addition, what follows is a prototype version of the rubric to measure and visualize interactivity from the teacher's perspective. See Table 4. Each component is broken down to six scales. The total score is forty points. The higher the point is, the more interactive the contents is. The score of each component could be displayed in the radar chart to visually show strong points as well as weak points. 
Table 4. Rubrics: Interactivity from the teacher

\begin{tabular}{|c|c|c|c|c|c|c|c|c|}
\hline \multicolumn{4}{|c|}{ Components of interactivity from the teacher's perspective } & & \multirow[b]{2}{*}{1} & \multirow[b]{2}{*}{0} & \multirow[b]{2}{*}{ subtotal } \\
\hline Component & Description & 5 & 4 & 3 & 2 & & & \\
\hline [ learning trigger ] & $\begin{array}{l}\text { Are there things } \\
\text { on the page or } \\
\text { site to spark } \\
\text { insight and } \\
\text { discovery? }\end{array}$ & $\begin{array}{l}\text { There are many } \\
\text { learning triggers } \\
\text { to arouse } \\
\text { curiosity of } \\
\text { learners } \\
\text { throughout the } \\
\text { contents. } \\
\end{array}$ & $\begin{array}{l}\text { There are many } \\
\text { learning triggers } \\
\text { to arouse } \\
\text { curiosity of } \\
\text { learners. }\end{array}$ & \begin{tabular}{|l|} 
There are some \\
triggers to arouse \\
curiosity of \\
learners.
\end{tabular} & $\begin{array}{l}\text { There are a few } \\
\text { Itriggers to arouse } \\
\text { euriosity of } \\
\text { learners. } \\
\text { l }\end{array}$ & $\begin{array}{l}\text { There are few } \\
\text { triggers to arouse } \\
\text { curiosity of } \\
\text { learners. }\end{array}$ & $\begin{array}{l}\text { The contents is } \\
\text { nothing but the } \\
\text { description of } \\
\text { knowledge. }\end{array}$ & \\
\hline [ new connection ] & $\begin{array}{l}\text { Are there } \\
\text { features to create } \\
\text { new connections } \\
\text { in the student's } \\
\text { mind? }\end{array}$ & $\begin{array}{l}\text { There are such } \\
\text { features } \\
\text { throughout the } \\
\text { contents. }\end{array}$ & $\begin{array}{l}\text { There are many } \\
\text { features. }\end{array}$ & $\begin{array}{l}\text { There are some } \\
\text { features. }\end{array}$ & $\begin{array}{l}\text { IThere are a few } \\
\text { f features. }\end{array}$ & $\begin{array}{l}\text { There are few } \\
\text { features. }\end{array}$ & $\begin{array}{l}\text { There is no such } \\
\text { feature. }\end{array}$ & \\
\hline [ routine breaker ] & \begin{tabular}{|l|} 
Are there \\
surprises \\
implemented to \\
break routine \\
activities?
\end{tabular} & $\begin{array}{l}\text { There are routine } \\
\text { breakers } \\
\text { throughout the } \\
\text { contents. }\end{array}$ & $\begin{array}{l}\text { There are many } \\
\text { routine breakers. }\end{array}$ & $\begin{array}{l}\text { There are some } \\
\text { routine breakers. }\end{array}$ & $\begin{array}{l}\text { There are a few } \\
\text { Iroutine breakers. } \\
\text { I }\end{array}$ & $\begin{array}{l}\text { There are few } \\
\text { routine breakers. }\end{array}$ & $\begin{array}{l}\text { There is no } \\
\text { routine breaker. }\end{array}$ & \\
\hline [ emotion ] & $\begin{array}{l}\text { Are there } \\
\text { features to make } \\
\text { students laugh, } \\
\text { smile, mad, even }\end{array}$ & \begin{tabular}{|l|} 
Such features are \\
present \\
throughout the \\
contents.
\end{tabular} & $\begin{array}{l}\text { There are many } \\
\text { such features. }\end{array}$ & $\begin{array}{l}\text { There are some } \\
\text { such features. }\end{array}$ & $\begin{array}{l}\text { There are a few } \\
\text { Isuch features. }\end{array}$ & $\begin{array}{l}\text { There are few } \\
\text { such features. }\end{array}$ & $\begin{array}{l}\text { There is no such } \\
\text { feature. }\end{array}$ & \\
\hline [ feedback ] & $\begin{array}{l}\text { Are there } \\
\text { features to give } \\
\text { feedback to what } \\
\text { students question }\end{array}$ & \begin{tabular}{|l|} 
There are such \\
features \\
throughout the \\
contents. \\
\end{tabular} & $\begin{array}{l}\text { There are such } \\
\text { features in most } \\
\text { of contents. }\end{array}$ & $\begin{array}{l}\text { There are such } \\
\text { features in some } \\
\text { of contents. }\end{array}$ & $\begin{array}{l}\text { There are a few } \\
\text { Ifeatures in } \\
\text { contents. }\end{array}$ & $\begin{array}{l}\text { There is few such } \\
\text { features. }\end{array}$ & No such feature. & \\
\hline $\begin{array}{l}\text { [ frequency of } \\
\text { feedback ] }\end{array}$ & $\begin{array}{l}\text { How frequently } \\
\text { is feedback given } \\
\text { to students? }\end{array}$ & \begin{tabular}{|l} 
Feedback is \\
given every time \\
a student asks a \\
question.
\end{tabular} & $\begin{array}{l}\text { Feedback is } \\
\text { given almost all } \\
\text { times. }\end{array}$ & $\begin{array}{l}\text { Feedback is } \\
\text { given most of } \\
\text { times. }\end{array}$ & $\begin{array}{l}\text { Feedback is } \\
\text { given } \\
\text { occasionally. }\end{array}$ & $\begin{array}{l}\text { Feedback is } \\
\text { rarely given. }\end{array}$ & $\begin{array}{l}\text { There is not } \\
\text { feedback given. }\end{array}$ & \\
\hline $\begin{array}{l}\text { [ time lag before } \\
\text { feedback ] }\end{array}$ & $\begin{array}{l}\text { How long do } \\
\text { students wait } \\
\text { before receiving } \\
\text { feedback? Is the } \\
\text { time lag } \\
\text { effectively used? }\end{array}$ & $\begin{array}{l}\text { The time lag to } \\
\text { feedback is } \\
\text { effectively used } \\
\text { constantly. }\end{array}$ & $\begin{array}{l}\text { The time lag to } \\
\text { feedback is } \\
\text { effectively used } \\
\text { at most of times. }\end{array}$ & $\begin{array}{l}\text { The time lag is to } \\
\text { feedback is } \\
\text { sometimes used } \\
\text { effectively. }\end{array}$ & $\begin{array}{l}\text { The time lag to } \\
\text { Ifeedback is } \\
\text { occasionally } \\
\text { effective. }\end{array}$ & $\begin{array}{l}\text { The time lag to } \\
\text { feedback is rarely } \\
\text { considered. }\end{array}$ & $\begin{array}{l}\text { There is no time } \\
\text { lag to feedback } \\
\text { considered. }\end{array}$ & \\
\hline [ varicty of payoffs ] & $\begin{array}{l}\text { Is there enough } \\
\text { variety to have } \\
\text { different payoff's } \\
\text { based on } \\
\text { different actions? }\end{array}$ & $\begin{array}{l}\text { There are } \\
\text { excitements } \\
\text { throughout the } \\
\text { contents. }\end{array}$ & $\begin{array}{l}\text { There are many } \\
\text { excitements in } \\
\text { the contents. }\end{array}$ & $\begin{array}{l}\text { There are some } \\
\text { excitements in } \\
\text { the contents. }\end{array}$ & $\begin{array}{l}\text { There are a few } \\
\text { iexcitements in } \\
\text { the contents. }\end{array}$ & $\begin{array}{l}\text { There are few } \\
\text { excitements in } \\
\text { the contents. }\end{array}$ & $\begin{array}{l}\text { There is only } \\
\text { cliché payofts. }\end{array}$ & \\
\hline Total SCORE : & & & & & 1 & & & \\
\hline
\end{tabular}

In this approach, interactivity is assessed from two perspectives, namely, from the perspective of students and from the perspective of the teacher separately. We consider that the two perspectives are necessary for measuring the interactivity that leads to learning effectiveness.

\section{Conclusions}

We have tried to give working definition of "interactivity," "knowledge," "experience," and "learning environment" in this paper. In any theory, theoretical constructs, and methodology are the keys to make the research successful. In the approach to measure interactivity, we employed such theory-building strategy. 
Our intention here is not to come up with a nifty evaluation procedure to evaluate the interactive multimedia, but rather a practical evaluation measure to rate an aspect of interactivity for the interactive multimedia software for the Internet. Because not many literatures discuss interactivity in the sense presented in this paper, we had to work on our own evaluation measure based on Dewey's learning theory and others who contributed in the study of learning interactivity. This paper also demonstrated how the interactive assessment tool is used. We hope that such a measure for interactivity that leads learning effectiveness will be used for multimedia or e-Learning contents uniformly so that teachers can rely on it as a standardized guide to choose learning contents for their students.

\section{References}

1 Dewey, J. (1913). Interest And Effort in Education. Boston: Houghton Mifflin Company.

2 Dewey, J. (1897). My Pedagogic Creed. School Journal, 54, 77-80.

3 Dewey, J. (1938). Experience and Education. New York: Touchstone.

4 Doll. R. C. (1996). Curriculum Improvement. Boston: Allyn and Bacon.

5 Flinders, D.J., \& Thornton, S.J. (1997). The Curriculum Studies Reader. New York: Routledge.

6 Geoghegan, W. H. (1994). Stuck at the barricades: Can information technology really enter the mainstream of teaching and learning? AAHE Bulletin, September, 13-16.

7 Jonassen, D., \& Mayes, J.T. (1993). A Manifesto for a Constructivist Approach to Technology in Higher Education. Available online: http://www.icbl.hw.ac.uk/ctl/msc/ceejw1/ paper11.html.

8 Pearce, C. (1997). the interactive book: a guide to the interactive revolution. Indianapolis: MacMillan Technical Publishing.

9 Reeves, T. (1992). Effective dimensions of interactive learning systems. Invited keynote paper presented at the Information Technology for Training and Technology (ITTE '92) Conference, Queensland, Australia.

10 Reeves, T., \& Harmon, S. (1994). What's in a name: Hypermedia versus multimedia. Interact Journal, 3(1), 28-30.

11 Reeves, T. (1999). Evaluating Interactivity. A half day workshop in AECT 1999 Conference.

12 Thorndike, E. L. (1913). Educational Psychology. The psychology of learning (Vol.2). New York: Teachers College Press.

13 Tobin, K., \& Dawson, G. (1992). Constraints to curriculum reform: Teachers and the myths of schooling. Educational Technology Research and Development, 40(1), 8192. 